\title{
Project management relationship to green innovation processes in sustainable fabric companies
}

\author{
Relação entre gestão de projetos e inovação verde em \\ empresas de tecidos sustentáveis
}

\author{
Isabel Cristina Scafuto ${ }^{1}$ \\ Valdemilson de Assis Alves de Araújo ${ }^{2}$ \\ Andrea dos Anjos Moreiras ${ }^{3}$ \\ Cláudia Terezinha Kniess ${ }^{4}$
}

${ }^{1}$ PhD in Administration, Professor and Researcher, Programa de Pós-Graduação em Gestão de Projetos, Universidade Nove de Julho (Uninove), São Paulo, Brazil E-mail: isabelscafuto@gmail.com

${ }^{2}$ Master's Degree in Administration, PhD Student, Programa de Pós-Graduação em Gestão de Projetos, Universidade Nove de Julho (Uninove), São Paulo, Brazil E-mail: araujovaa.gp@gmail.com

\footnotetext{
${ }^{3}$ Master's Degree in Environmental Management and Sustainability, PhD student, MBA Fashion Professor, Programa de Pós-Graduação em Design, Universidade Anhembi Morumbi (UAM), São

\section{ABSTRACT}

The concept of green innovation refers to innovation that seeks to make radical or progressive improvements to products or processes that contribute to sustainable development. Green innovation can improve the global image of a business and lead to better market performance. Green innovation projects can contribute to economic growth and a positive quality of life without negatively affecting the environment. Consequently, this study aims to examine the relationship between the development of green materials resulting from green innovation and project management. To achieve the research objective, we conducted a multi-case study with companies developing green innovation derived textile. The findings show that the firms surveyed do not use formal project management to execute their green innovation projects and that their project management is intuitive. Although the companies 
surveyed are concerned with sustainable development and strive to innovate to satisfy their customers responsibly, their project management practices are informal. This study contributes to the practice. It is possible to introduce project management into enterprises to enhance green innovation while adapting practices or using less formal and bureaucratic techniques.

Keywords: Management of Innovative Projects. Sustainable Project Management. Green Innovation. Sustainable Fabrics.

\section{RESUMO}

O conceito de inovação verde refere-se ao tipo de inovação dedicada para a obtenção de melhorias radicais ou incrementais de produtos ou processos que contribuam para o desenvolvimento sustentável. A inovação verde pode melhorar a imagem geral de uma empresa e, como consequência, pode levar a um melhor desempenho no mercado. Os projetos de inovação verde podem colaborar para o crescimento econômico, possibilitando qualidade de vida sem prejudicar o meio ambiente. Assim, o objetivo deste estudo é verificar como se caracteriza a relação do desenvolvimento de tecido derivado da inovação verde com o gerenciamento de projetos. Para alcançar o objetivo da pesquisa, foi realizado um estudo de multicasos com empresas desenvolvedoras e utilizadoras de tecidos derivados da inovação verde. Os resultados obtidos indicam que as empresas estudadas não usam gestão de projetos formal na condução de seus programas de inovação verde. A gestão de projetos é totalmente intuitiva. Embora as empresas pesquisadas estejam preocupadas com a sustentabilidade e querendo cada vez mais inovarem com responsabilidade para satisfazerem seus clientes, as práticas de gestão de projetos são informais. Este estudo contribuiu para a prática, no sentido de que existe a oportunidade de implementação da gestão de projetos nas empresas com o intuito de melhoramento da inovação verde, embora com a necessidade de adaptação ou uso de técnicas menos formais e burocráticas.

Palavras-chave: Gestão de Projetos Inovadores. Gestão de Projetos Sustentáveis. Inovação Verde. Tecidos Sustentáveis.

\section{INTRODUCTION}

The academic community and companies have progressively expressed interest in sustainability, which directly triggers increased pressure on companies to recognise ecological awareness (HART, 2005). Innovation has been recognised as an ally of sustainability, so that it is part of the strategic agenda for creating a competitive advantage for companies (SHAFIQUE, 2013). This is considered a critical factor for developing a more inclusive and sustainable world, which "involves creating and disseminating new products, processes, and methods" (OECD/Eurostat, 2015). Innovation is not a final objective but the fundamental basis for creating new businesses and jobs, and consequently, for the economic development of nations.

The literature presents different ways to integrate Innovation and Sustainability themes, such as green innovation, ecological, environmental, and sustainable innovation (TARIQ et al., 2017). This research addresses green innovation, defined as new products and processes that provide value to customers and businesses and significantly mitigate adverse environmental impacts (KONG; FENG; YE, 2016). Green product innovation generates the design, production, and sale of products with no significant adverse effect on the environment throughout the product's life cycle. It includes ensuring efficient use of materials and reducing pollutants (AMBEC; LANOIE, 2008). Green process innovation is seen as progress in technologies and processes that create products with little or no negative environmental impact (HUANG; LI, 2017; SEZEN; ÇANKAYA, 2013). One example is recycling materials to reduce waste and improve inputs, thus contributing to profitability (FRAJ-ANDRÉS; MARTINEZ-SALINAS; MATUTE-VALLEJO, 2009).

Green innovation can improve a company's overall image and lead to better performance in the market (TARIQ et al., 2017). The positive reputation associated with green innovation increases the company's 
market value (MAJUMDAR; MARCUS, 2001). Better environmental performance can facilitate new market opportunities, improve the public image or prestige, increase customer loyalty, and support sales efforts (AMBEC; LANOIE, 2008).

There is a gap in the management level of companies concerning the incorporation of aspects of sustainability into organisational processes. Therefore, there is a need for the environmental, social, and economic dimensions to be inserted and worked into the project management function and in product development, thus aiming at sustainability (AARSETH et al., 2017; HERNÁNDEZ et al., 2020; SABINI et al., 2019). Projects characterised as "green innovation" can collaborate with economic growth, enabling positive quality of life without harming the environment (BOTKIN; KELLER, 2011). However, small and medium companies (SMEs) have difficulties in using project management practices (TURNER; LEDWITH; KELLY, 2010), especially in sustainability, due to increasing complexity (ESKEROD; HUEMANN, 2013; SILVIUS et al., 2012).

The growing concern with the environment has influenced the textile industry as it is responsible for negative impacts related to pollution (CHEN et al., 2017; SAN et al., 2018). To minimise pollution caused by the textile industry is one of the main concerns for sustainability (AMINDOUST; SAGHAFINIA, 2016). Innovative fabrics with sustainable appeal have been created over the years (VALLE et al., 2004). Although not yet prevalent, sustainable materials are gaining space among brands (COLERATO, 2016), inspiring innovation in the fashion market.

Many innovative sustainable fabric companies are small or medium-sized, and innovation through entrepreneurial activity is usually essential for its contribution to the economy and the development of green innovation. This study aims to verify the character of the development of fabrics derived from green innovation and project management. We performed a multi-case study with companies that develop technologically innovative and sustainable materials to achieve the research objective.

The results indicate that despite the potential of using project management tools to improve green innovation, SMEs dedicated to sustainable fabric products do not use formal techniques to manage their projects. We would argue that it's because of its size and the technical focus on innovation development.

\section{THEORETICAL FOUNDATION}

\subsection{INNOVATIVE GREEN PROJECT MANAGEMENT}

The growth of industrial activity, with the consequent generation of a more significant amount of waste and pollutants along with the increase in demand for products and services, has forced the simultaneous development of new technologies for production processes with the need for further administrative techniques aimed at managing these activities while attuned to environmental concerns (SABINI et al., 2019). Concurrently, governments began to dedicate efforts to searching for solutions to environmental problems through specific regulatory bodies and the attempt to implement agreements resulting from international conferences. Standardising bodies started to work on technical standards to guide companies (AGARCHAND; LAISHRAM, 2017).

The project management area has taken on an essential role in companies, going through a transformation process, organising itself to provide effective and agile answers to the questions that belong to it (CARVALHO; RABECHINI JÚNIOR, 2011). Innovation and the development of new products and/or services are strongly associated with modern project management (COUTINHO; GIL, 2013). Rational project management approaches include ways to address the unexpected (SICOTTE; DROUIN; DELERUE, 2014), thereby helping achieve the goals of a new product and/or new business technology (COOPER; EDGETT; KLEINSCHMIDT, 1999; ROUSSEL; SAAD; ERICKSON, 1991). 
Innovative green projects can contribute to economic growth, enabling positive quality of life without harming the environment (AARSETH et al., 2017). Many companies apply good project management practices, and this area has gained importance in companies seeking agile responses in their business processes and projects. Sustainability has aroused the interest of professionals and researchers in project management (SILVIUS; SCHIPPER, 2015). Even so, there is a gap between understanding and using sustainability in project management practice (MARTENS; CARVALHO, 2016). Several scientific works are available in sustainability and project management, but no research links the two areas (MARTENS; CARVALHO, 2016).

It is critical to emphasise the application and learning process around green innovation generates an advantage in improving, minimising cycle times, and unnecessary procedures in production (SERRANOGARCÍA et al., 2021). Project managers need to be relatively autonomous to overcome each raw material's legislative and technological challenges in a sustainable and innovative product or process (WILLEMS et al., 2020). To become competitive, managers must use their knowledge or skills to apply important green strategic innovations (SERRANO-GARCÍA et al., 2021).

This work aims to verify the relationship between developing innovative green products and project management in SMEs. To understand this relationship, we used fabrics made with green innovation technology as the focus of our study.

\subsection{SUSTAINABLE FABRICS}

Sustainable fabrics are gaining space among brands that are thinking about best practices for sustainable production. In general, the focus of innovation projects in the textile industry has been the exchange of synthetic materials for natural materials (NAYAK; MISHRA, 2016; ZHANG et al. 2016) and the search for less pollutant manufacturing processes (BENLI; BAHTIYARI, 2015; EL-GOHARY et al., 2013; Ll et al., 2018).

These fabrics are increasingly inspiring innovation in the fashion market (SU-YUN; JUNG-MIN, 2010). One of the most common types of eco-friendly fabric is defibrated (CANDIDO, 2021). Defibrated fabrics are those with yarns obtained using defibrated material from longstanding tissue waste. Research and new developments allowed the fashion market to start using them to produce new products. Defibrated fabrics have resistance, are comfortable and attractive. In addition to the environmental issues that make the fi more attractive than conventional fabrics, the appearance is another positive advantage of the product (PALME et al., 2017).

Sustainable and innovative textile raw material alternatives are steadily emerging. They are not harmful to the environment and use materials that would be discarded (CANDIDO, 2021). In Frame 1, we present some alternatives that entered the market to help strengthen this niche (MAGAZINE, 2020):

Frame 1 | Sustainable and innovative textile raw material alternatives

\begin{tabular}{cc}
\hline Kind of Fabric & Description \\
\hline $\begin{array}{l}\text { Organic } \\
\text { cotton }\end{array}$ & Reduced use of chemicals, in addition to other natural resources \\
Hemp & $\begin{array}{c}\text { One of the most sustainable vegetable fibres in the world. It is grown near rivers and } \\
\text { produced from the Cannabis sativa plant, and it does not need chemicals like herbicides and } \\
\text { pesticides to grow. }\end{array}$
\end{tabular}

Banana fibre

It is extracted from the trunk of the banana tree, thus avoiding its disposal. Material of excellent resistance and looks like silk and cotton. 


\begin{tabular}{|c|c|}
\hline Kind of Fabric & Description \\
\hline Orange fibre & Made from the orange pulp cellulose used in juice factories, the orange has a finish like that of silk. \\
\hline $\begin{array}{l}\text { Pirarucu } \\
\text { leather }\end{array}$ & $\begin{array}{l}\text { A fish native to the Brazilian Amazon and its cultivation is one of the primary sources of income for } \\
\text { families in this region. }\end{array}$ \\
\hline Soy fibre & Made from leftover soybean processing, soy silk is another sustainable fabric. \\
\hline Lenpur & $\begin{array}{l}\text { Made from the white pine tree, lenpur is a soft biodegradable fabric with a great absorption capacity } \\
\text { and moisture release. }\end{array}$ \\
\hline Linen & $\begin{array}{l}\text { Linen is a sustainable fabric used since ancient civilisations. The fibres are removed from its stem and } \\
\text { root. }\end{array}$ \\
\hline Lyocell & $\begin{array}{l}\text { Lyocell is a fiber that uses chemicals free of harmful solvents in its production. It is made from wood } \\
\text { pulp. }\end{array}$ \\
\hline Modal & $\begin{array}{c}\text { It is made from the bark of wood. The material is extracted in the same place where the fibre is } \\
\text { produced. }\end{array}$ \\
\hline Piñatex & $\begin{array}{l}\text { Extracted from the pineapple fibres and is leather. It has the same function as animal or synthetic } \\
\text { leather and does not generate extra costs for its production, such as water or pesticides. }\end{array}$ \\
\hline $\begin{array}{l}\text { Degradable } \\
\text { polyamide }\end{array}$ & $\begin{array}{c}\text { Developed so that clothing can decompose more quickly after being discarded, biodegradable } \\
\text { polyamide is a fibre that degrades in just three years. }\end{array}$ \\
\hline Qmilk & $\begin{array}{l}\text { It comes from milk protein, from curdled milk that the industry would discard. In addition to being an } \\
\text { all-natural fibre, it requires low water consumption and no addition of chemicals. }\end{array}$ \\
\hline
\end{tabular}

Source: Adapted from MAGAZINE (2020)

\section{METHODOLOGICAL PROCEDURES}

\subsection{RESEARCH DESIGN}

We designed the research to minimise the external variation of the studied phenomenon (EISENHARDT, 1989). The authors considered some theoretical dimensions relevant to fabric companies' choice as a sample for data triangulation. We selected the companies based on two criteria applicable to the research. First, they would have to be classified as being sustainable. Second, they would have to work with fabrics developed with technological innovation. The selected companies are consolidated sustainably and innovatively market, which meets the profile established by this research proposal. The intention of researching sustainable and innovative fabrics is to show the fashion industry that sustainable alternatives do not harm the environment and generate a competitive advantage for companies, aiming at the tripod of sustainability.

\subsection{DATA COLLECTION}

To conduct the research, we used multiple sources of evidence (EISENHARDT, 1989). This process implemented the triangulation of primary and secondary data: information from websites, news, company documents, bibliographic research on the subject, and semi-structured interviews with executives of the manufacturing companies. Thus, to conduct interviews with the managers of the fabric companies, we analysed the secondary data sources. This was so that the researcher could become familiar with the companies before starting the semi-structured interviews. Additionally, it helped with triangulation and the development of an essential document for later analysis of cases. Although the primary data source is derived from semi-structured interviews (SAUNDERS; THORNHILL; LEWIS, 2009), this other information facilitated the elaboration of the questions used in the interviews and the later triangulation of the data. Knowing the intentions and experiences of key actors directly involved in projects to develop green innovation fabrics is essential. We concluded the interviews with some precautions for their conduct, such as the use of short expressions, rewording, and supplementary questions (SAUNDERS; THORNHILL; LEWIS, 2009). 
Frame 2 presents the companies participating in the research, the interviewees, and their respective positions.

Frame 2 | Companies and their key players with their respective positions

\begin{tabular}{clc}
\hline Company & Code & Position in the company \\
\hline Movin & E1 & Managing partner \\
$\begin{array}{c}\text { Anicet Clothing and Services in Fashion } \\
\text { and Style Inc. (Contexture) }\end{array}$ & E2 & Managing partner \\
Cotton Move & E3 & Managing partner \\
Natural Cotton Color & E4 & Managing partner
\end{tabular}

Source: The authors.

Frame 3 shows the script for the semi-structured interviews. The elaboration of the questions observed a previous validity relating the research to the theory.

Frame 3 | Semi-structured interview script

Questions

Theoretical foundation

Descriptive information of the interviewees and the company: name of the interviewee, name of the company, and the interviewee's position, etc.

Would you please tell me your company's story and how the idea of sustainable fabrics was born?

Candido (2021), Colerato (2016)

What are sustainable fabrics in the concept established by the company? Candido (2021), Colerato (2016)

What types of fabric are manufactured today, and what characterises them as sustainable?

Su-Yun and Jung-Min (2010) Colerato (2016), Tariq et al. (2017)

How was the first sustainable product developed?

TARIQ et al. (2017)

From this, how is the project management of the development of the new fabrics' project?

Martens and Carvalho (2016)

Planning - Is there any formalisation of the fabric development project, in which aspects of the project's scope, time to completion, development cost, materials, and suppliers are discussed, as well as steps and actions to make it happen? If so, how does it happen?

Execution, Monitoring and Control - How does the project run? Does the development project take place separately from the production? Are there formal follow-up meetings? Is there a person responsible for development? Are there controls to assess progress? How are interventions made to correct the directions? Are there records of fabric developments?

Closure - How does it happen, and what are the decision criteria that the project is closed - fabric ready to produce and sell? Is there any criterion for evaluating the success of the executed project? Are records of the entire project and the steps kept supporting future developments?
HAANAES et al. (2011).

Martens and Carvalho

(2016), HAANAES et al. (2011). 


\section{RESULTS}

\subsection{MARKET CHARACTERIZATION}

Starting in the 1990s, the fast-fashion market proliferated. According to the BBC, the fashion industry occupied second place in the ranking of the most polluting in the world (JORNALISMO NIC, 2018). Faced with this dilemma, concern for a better world awoke new habits in the population, and sustainable fashion or eco-fashion emerged. Realising this need for change in the fashion sector, sustainable fashion is still timid and covers approximately $5 \%$ of the Brazilian population (JORNALISMO NIC, 2018).

The growth of the sustainable fashion sector suffers some obstacles, such as heavy investment in research and development in technological innovation. Another factor, which can be considered an obstacle, is the product's price that reaches the final consumer. They are still more expensive than fast fashion. This is due to artisanal confection and on a smaller scale. Another factor to consider is fair trade; the professionals involved in designing, cutting, and sewing receive a fair wage. Thus, this timid change that has arisen in fashion requires awareness for the product's whole life cycle and the consumer. Slow fashion is already a reality and addresses improved environmental, social and transparency conditions in the production line (JORNALISMO NIC, 2018).

\subsection{CHARACTERIZATION OF THE STUDIED COMPANIES}

The following sections present the companies participating in the research and their main characteristics.

\subsubsection{MOVIN COMPANY}

Movin was founded in 2011 in Rio de Janeiro with the main idea to bring the sustainability tripod as a fundamental pillar of ethics and bring design and technology. The company launched all products as initiatives that were truly sustainable through research. Since 2011, the company has been transparent about bringing innovations, solutions for fabrics, other processes within the company, and communication.

\subsubsection{COMPANY ANNE ANICET CLOTHING AND SERVICES IN FASHION AND STYLE INC. (AA FASHION) - CONTEXTURE}

Anne Anicet Clothing and Services in Fashion and Style Inc (AA Fashion) - Contexture is in Porto Alegre, RS - Brazil. Contexture is a South Brazilian brand of ethical fashion with a slow-fashion philosophy. Companies cut their pieces through artistic processes so that new relationships can be established in use. This is based on textures as raw material and sustainability to improve the quality of life.

\subsubsection{COTTON MOVE COMPANY}

Cotton Move, founded in 2018, is from São Paulo. It is a textile company that produces jeans using recycling techniques and believes it can transform fashion into quality products. Its mission is to propagate a sustainable fashion concept that meets the needs of the conscious consumer. Their objectives are to develop research and technology and manufacture and distribute products while generating capital and profits without disrespecting the environment. 
Natural Cotton Color was established in 1995 in Paraíba as a streetwear fashion, under the name of its founder and managing partner, Francisca Vieira. In 2001, it included local handicrafts in its collections and participated for the first time in a fashion event: The National Textile Industry Fair - NTIF. As of 2005, Natural Cotton Color works strictly with the Paraíba Colored Cotton developed by the Brazilian Agricultural Research Company - Embrapa, cotton whose plume is born in brown and beige tones, without the use of additives or dyes. It also added artisanal work in designing its products - aligning the brand with eco-friendly and sustainable fashion.

\subsection{GREEN INNOVATION AND ITS RELATION TO PROJECT MANAGEMENT}

The results of the qualitative analysis of the semi-structured interviews were processed using the MAXQDA software, which produced a map (Figure 1). The numbers identified in the figure represent the number of co-occurrences coded by the researcher. Extracts complement the presentation of the results from the interviews for a better understanding of the reader. Each respondent was identified with a code verified in Frame 2.

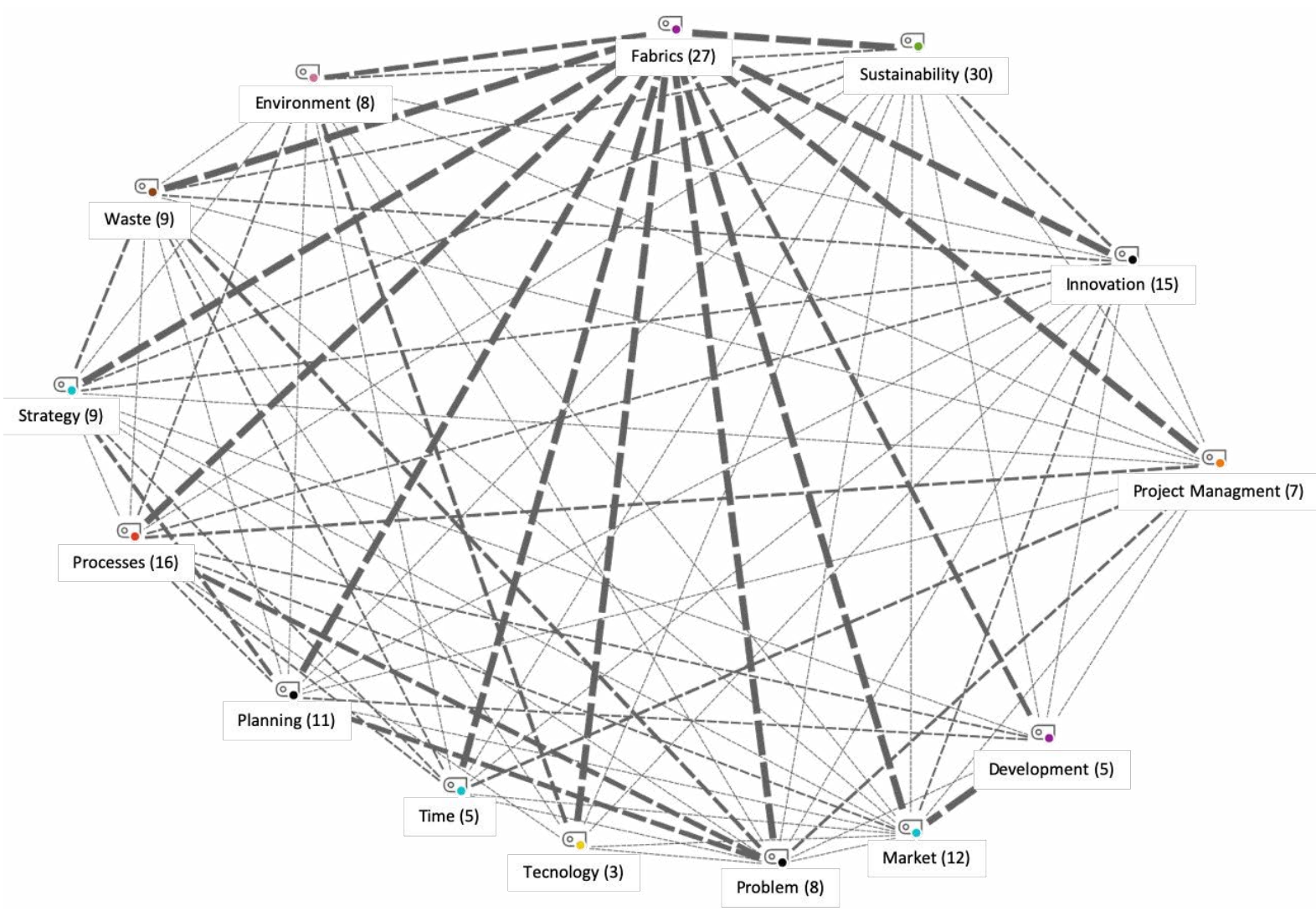

Figure 1 | Green innovation and possible relations with project management

Source: The authors

From Figure 1, it is possible to check the relationships between the codes identified in the interviews with companies developing green innovation fabrics. The principal codes extracted from the research are project management, sustainability, and innovation. These codes are directly related to the research objective. Innovation and sustainability are closely linked and were frequently mentioned during the interviews. This high number of citations is due to the research object, the fabrics developed with technological and sustainable innovations. It is possible to verify this strong relationship based on statements made by some interviewees. 
The interviewee of the company Contexture (E2) reported that "Apply theories sustainably in practice and check what worked and what didn't. With that, over the years we have been testing various sustainable strategies, some have worked, others not so much".

According to the interviewee (E3), manager of the company Cotton Move,

At the suggestion of a business partner, we decided to focus on defibration because the problem of textile waste is more serious than the problem of cotton. In this context of conventional cotton and organic cotton production, waste is more problematic. There are not hundreds, but thousands of tons per day, per month, which does not have a solution, here in Brazil.

There is a concern with some innovations considered sustainable, seen in the interview of the company Natural Cotton Color, interviewee (E4):

So, we try to put the tripod of sustainability and the cultural part in a brand and, for me, this I can call sustainability. It is not always possible to have four pillars, but it is difficult if you do not have at least two. For me, the recycled PET is not to push the problem to tomorrow; you know that problem that we have to solve today.

The interviewee shows concern about the fabric made of plastics originating from the PET. This is because there is a discussion regarding the disposal of this type of fabric and microplastics.

Sustainability relates to other codes that are important for understanding relationships with a whole, such as fabrics. All companies interviewed are manufacturers or develop products from sustainable fabrics. Another interesting connection is that of sustainability with strategy, and respondents made this relationship explicit. Respondents stated that an essential strategy for the company is to work with the green innovation fabric differential. They still use methods to understand the market and manufacture new fabrics. This is evident in the speech of interviewee E1 who reported: "based on results and market information, as we do not produce from our idea, that is, we do not find and simply launch a product. First, we research to understand what the consumer wants, to produce later". Another statement that has a strong relationship with strategy comes from the interviewee E2: "With this, over the years we have been testing various sustainable strategies, some have worked, others not so much".

With the project management code, the relationship is not as strong with the themes of sustainability and innovation. The interviewees talked about working with projects, but it is transparent that it is not formally, but intuitively. For example, in the interviewee's E3 report, project management is timidly related to sustainability and innovation: "Water, energy, labour. So, the more we can recycle, and I don't just say that in my area. Today we focused on jeans, but, at various stages of the project, we are going to get fabrics and other fibres".

It is observed that interviewee E3 talks about the concern with sustainability, the search for new fabrics with green innovation, and mentions the stages of the project. However, there is no evidence in the interviews that prove the proper use of project management or even reports the existence of a collaborator focused on the conduct of projects. This lack of connection with project management is evident in the interviewee's E4 statement: "The creation of a new product is a straightforward thing, there are no major studies, research, I have to have a supplier, input, which is cotton, then spin, weave, transform into clothes and sell. So, there is not much to plan".

Project management is also related to the processes in the companies surveyed. This is because the interviewees show they control the processes within the design of each product. Regarding this, interviewee E3 reports: "The records are already made in the product's technical sheet, in the Excel spreadsheet and where it is done even the records of what is produced in that article". Generally, jeans articles have a slightly longer life cycle than other pieces. The final product has some samples where 
some customers participate in the decision process. The success of the sale will determine how long the product will survive in the sales arena. If it is a best-seller, it can be maintained throughout the entire collection. It can be produced in several units, or it simply may not be to the consumer's liking and then in the next project, we understand the errors, redo the adjustments, and adapt to produce a new product for the vision that the consumer has to acquire the product.

\section{DISCUSSIONS}

This study aimed to verify the characteristics of the development of fabrics derived from green innovation and project management. We studied companies that manufacture or develop fabrics derived from the sustainable technological innovation process to accomplish this. We interviewed managers of four different companies. In addition to the semi-structured interviews, we collected secondary data, such as information on the companies' websites, reports, and documents. These data served to triangulate the data. This multiple case study made it possible to analyse real experiences in the context of the chosen theories.

Factoring in the growing awareness of the need to minimise the environmental impact of the textile industry (AMINDOUST; SAGHAFINIA, 2016; SAN et al., 2018), and the interest in sustainable fabrics (COLERATO, 2016), it is important to assess the role of SMEs dedicated to this type of product. In this study, these SMEs can be classified as sustainability-driven companies (ALBINO; BALICE; DANGELICO, 2009). The statements indicate that their interest goes beyond the interest of legitimacy and financial gain (TARIQ et al., 2017) of sustainability-driven innovation (KIRON et al., 2013).

This represents the genuine interest of the interviewed entrepreneurs of these studied companies. Although, they also believe that green innovation is a differential to stand out in the increasingly competitive strategic market. For example, although defibrated fabrics use defibrated material from fabric scraps, like PET, some entrepreneurs said this mitigates but is not a definitive solution. They prefer to substitute for natural materials (NAYAK; MISHRA, 2016; ZHANG et al., 2016) and improve their production process to become more sustainable (BENLI; BAHTIYARI, 2015; EL-GOHARY et al., 2013; LI et al., 2018).

Companies realize that working with green innovation is a smart strategy in such a competitive market. Despite the recognition of entrepreneurs that their companies participate for a more sustainable world, it also explains the positive reputation associated with green innovation and the possibility of these companies to capture value (MAJUMDAR; MARCUS, 2001). Better environmental performance can facilitate new market opportunities, improve the public image or prestige, increase customer loyalty, and support sales efforts (AMBEC; LANOIE, 2008).

The studied entrepreneurs said they work with projects. Still, it seems to indicate that they are more concerned with the technical features of the sustainable product project. We identified the replacement of synthetic by natural fabrics (MISHRA, 2016; NAYAK; TONG, 2016; ZHANG et al., 2016), and materials and techniques to turn the production process more sustainable (BENLI; BAHTIYARI, 2015; EL-GOHARY et al., 2013; Ll et al., 2018). Their focus does not consider the use of project management tools or best practices.

Our results indicate that SME entrepreneurs do not see an immediate reward for using the project management tools. They have little knowledge about project management tools and practices but believe it will be difficult (TURNER; LEDWITH; KELLY, 2010), and complex to use (ESKEROD; HUEMANN, 2013; SILVIUS et al., 2012).

They do not consider project management a competitive differential, as they manage their projects informally within the companies. Project management practices are not usually considered by SMEs, especially companies that are technically oriented. Project management practices tend to be formal and considered bureaucratic by SME managers (TURNER; LEDWITH; KELLY, 2010). 
However, the use of project management practices may improve sustainable, innovative product development (CARVALHO; RABECHINI JÚNIOR, 2011; COUTINHO; GIL, 2013), helping to achieve the goals of a new product and/or new business technology (COOPER; EDGETT; KLEINSCHMIDT, 1999; ROUSSEL; SAAD; ERICKSON, 1991). Larger companies usually use these practices, but we recognize the opportunity for SMEs to utilize them and contribute to Innovative green projects and their positive consequences (BOTKIN; KELLER, 2011).

The entrepreneurs from the companies of this work recognize this importance and the opportunity as a business. Although the theory indicates this possibility considering innovative and sustainable projects (SABINI et al., 2019), this study of multiple cases showed that companies do not formally use project management and that project management is used intuitively. It seems to be related to the nature of companies, SMEs (ESKEROD; HUEMANN, 2013; SILVIUS et al., 2012; TURNER; LEDWITH; KELLY, 2010). The entrepreneurs' concerns can be mitigated by adapting project management practices to the size and during companies' growth (TURNER; LEDWITH; KELLY, 2010), or the possibility of adopting more agile practices that are more agile collaborative and less bureaucratic.

Our study contributes to the management of sustainable innovation projects by pointing out the possibility and need to evaluate the use and adaptation of project management practices in SMEs. It contributes to the link between sustainability and project management, which is lacking in works that link the two areas of knowledge (MARTENS; CARVALHO, 2016) and reinforces the potential of using Project management practices in SMEs (TURNER; LEDWITH; KELLY, 2010).

\section{CONCLUSIONS}

This paper helps to clarify the potential and challenges of using project management tools and practices by SMEs dedicated to the development of innovative green fabric products. Businesses that work with green product innovation may miss the opportunity to incorporate formal project management into their daily lives. This is especially the case with SMEs, such as the companies in this study. According to the literature, adequate project management is essential for businesses that want to innovate. A company managing its projects well will drastically minimise difficulties in managing its innovations (BARNES, 1991).

This study has an inherent limitation in the multi-case study methodology. It is known that even though it is a study with multiple cases, it is not possible to have the desired scope. However, to compensate for this limitation, care was taken to triangulate the data, even with interviews as the primary data source. It is intended to evolve with this same research. The intention is to collect more interviews from the companies already selected and select other companies to participate in the study. The aim is to obtain a larger sample that allows more robust research.

As future recommendations, it is suggested that a quantitative survey be performed to confirm the constructs selected in the qualitative study. This will help ensure which constructs are appropriate for the proposed research and make it possible to offer a model that contemplates the use of project management in green innovation projects.

As practical results, this study contributes to the evidence that companies' managers and entrepreneurs can use by adapting project management tools and practices to improve their outcomes and sustainability. It also indicates the importance of professional associations and government actions to encourage and prepare entrepreneurs to use these project management practices effectively and adequately. 


\section{REFERENCES}

AARSETH, W. et al. Project sustainability strategies: a systematic literature review. International Journal of Project Management, v. 35, n. 6, p. 1071-1083, 2017.

AGARCHAND, N.; LAISHRAM, B. Sustainable infrastructure development challenges through PPP procurement process Indian perspective. International Journal of Managing Projects in Business, v. 10, n. 3, p. 642-662, 2017.

ALBINO, V.; BALICE, A.; DANGELICO, R. Environmental strategies and green product development: an overview on sustainability-driven companies. Business Strategy and Environment, v. 18, p. 83-96, 2009.

AMBEC, S.; LANOIE, P. When and why does it pay to be green? Academy of Management Perspectives, v. 23, p. 45-62. 2008.

AMINDOUST, A.; SAGHAFINIA, A. Textile supplier selection in sustainable supply chain using a modular fuzzy inference system model. J. Text. Inst., v. 108, n. 7, p. 1250-1258, 2016.

BARNES, M. Innovation - why Project management is essential to successful businesses. International Journal of Project Management, v. 9, n. 4, p. 207-209. 1991.

BOTKIN, D.; KELLER, E. Ciência Ambiental: Terra, um planeta vivo (7ạ edição). Rio de Janeiro: Gen/LTC. 2011.

CANDIDO, R. Recycling of textiles and its economic aspects. Md. IBRAHIM H. M. (Ed.). In the Textile Institute Book Series. Fundamentals of Natural Fibres and Textiles. Woodhead Publishing, p. 599-624, 2021.

CARVALHO, M.; RABECHINI JÚNIOR. R. Construindo competências para gerenciar projetos: teoria e casos. 3. ed. São Paulo: Atlas. 2011.

CHEN, L. et al. A process-level water conservation and pollution control performance evaluation tool of cleaner production technology in textile industry. J. Clean. Prod., v. 143, p. 1137-1143, 2017.

COLERATO, M. Três tecidos eco-friendly feitos no Brasil para uma produção mais sustentável. 2016. Available in: https://www.modefica.com.br/tecidos-eco-friendly-brasil/\#.W8ziwhNKjVo. Access on: 28 out. 2018.

CONTEXTURA. Available in: http://www.shopcontextura.com/. Access on: 7 set. 2021.

COOPER, R.; EDGETT, S.; KLEINSCHMIDI, E. New product portfolio management: practices and performance. Journal of Product Innovation Management, v. 16, n. 4, p. 333-350, 1999.

COTTON MOVE. Available in: https://www.facebook.com/cottonmove/. Access on: 7 set., 2021.

EISENHARDT, K. Building theories from case study research. Academy of Management Review, v. 14, n. 4, p. 532550, 1989.

ESKEROD, P.; HUEMANN, M. Sustainable development and project stakeholder management: what standards say. International Journal of Managing Projects in Business, v. 6, n. 1, p. 36-50, 2013.

FRAJ-ANDRÉS, E.; MARTINEZ-SALINAS, E.; MATUTE-VALLEJO, J. A Multidimensional Approach to the Influence of Environmental Marketing and Orientation on The Firm's Organizational Performance. Journal of Business Ethics, v. 88, n. 2, p. 263-286, 2009.

HAANAES, K. et al. First look: the second annual sustainability \& innovation survey. MIT Sloan Management Review, v. 52, n. 2, p. 77-83, 2011.

HART, S. Capitalism at the crossroads: the unlimited business opportunities in solving the world's most difficult problems. [s.I.]: Pearson Education. 2005.

HERNÁNDEZ, J. P. S.-I.; YAÑEZ-ARAQUE, B.; MORENO-GARCÍA, J. Moderating effect of firm size on the influence of corporate social responsibility in the economic performance of micro, small and medium-sized enterprises. Technol. Forecast Soc. Change, v. 151, p. 119-774, 2020. 
JORNALISMO NIC. Available in: http://portaldonic.com.br/jornalismo/2017/08/18/cresce-investimento-emmoda-sustentavel-no-brasil/. Access on: 7 set. 2021.

KIRON, D. et al. The benefits of sustainability-driven innovation. Sloan Management Review, v. 64, n. 2, p. 69-73, 2013.

KONG, T.; FENG, T.; YE, C. Advanced manufacturing technologies and green innovation: the role of internal environmental collaboration. Sustainability (Switzerland), v. 8, n. 10, p. 1056, 2016.

KUCKARTZ, U.; RÄDIKER, S. Vom Leitfaden Zum Kategoriensystem. In: Fokussierte Interviewanalyse mit MAXQDA. Springer VS, Wiesbaden. 2020.

KVALE, S. The Sage qualitative research kit. Doing interviews. Thousand Oaks, CA: Sage Publications Ltd. 2007.

MAGAZINE. 12 tipos de tecidos sustentáveis: moda que veio para ficar. Arccor Live Limitless. Available in: https:// all.accor.com/pt-br/brasil/magazine/one-hour-one-day-one-week/12-tipos-de-tecidos-sustentaveis-38838. shtml. Access on: 7 set. 2020.

MAJUMDAR, S.; MARCUS, A. Rules versus discretion: the productivity consequences of flexible regulation. Academy of Management Journal, v. 44, n. 1, p. 170-179, 2001.

MARTENS, M.; CARVALHO, M. Sustainability and Success Variables in the Project Management Context: an expert panel. Project Management Journal, v. 47, n. 6, p. 24-43, 2016.

MONAST, J.; ADAIR, S. A Triple Bottom Line for Electric Utility Regulation: aligning state-level energy, environmental, and consumer protection goals. Columbia Journal of Environmental Law, v. 38, n. 1, p. 1-65. 2013.

MOVIN. Available in: https://www.facebook.com/startmovin/. Access on: 7 set. 2021.

NATURAL COTTON COLOR. Available in: http://naturalcottoncolor.com.br. Access on: 7 set. 2021.

OECD/EUROSTAT. Oslo Manual: guidelines for collecting, reporting and using data on innovation, 4th. ed. Paris/ Eurostat, Luxembourg, 2018.

PÉREZ-PÉREZ, J. F.; PARRA, J. F.; SERRANO-GARCÍA, J. A system dynamics model: transition to sustainable processes. Technol. Soc., v. 65, p. 1-16, 2021.

ROUSSEL, P.; SAAD, K.; ERICKSON, T. Third generation R\&D: managing the link to corporate strategy. Boston: Harvard Business School Press. 1991.

SABINI, L.; MUZIO, D.; ALDERMAN, N. 25 years of "sustainable projects". What we know and what the literature says. International Journal of Project Management, v. 37, p. 820-838, 2019.

SAN, V.; SPOANN, V.; SCHMIDT, J. Industrial pollution load assessment in PhnomPenh, Cambodia using an industrial pollution projection system. Sci. Total Environ., v. 615, p. 990-999, 2018.

SAUNDERS, M.; LEWIS, P.; THORNHILL, A. Research Methods for Business Students. Pearson, New York, 2009.

SEEBODE, D.; JEANRENAUD, S.; BESSANT, J. Managing innovation for sustainability. R\&D Manage, v. 42, p. 195206, 2012.

SERRANO-GARCÍA, J. et al. Orchestrating capabilities, organizational dimensions and determinants in the pursuit of green product innovation. Journal of Cleaner Production, v. 313, p. 127-173, 2021.

SEZEN, B.; ÇANKAYA, S. Effects of Green Manufacturing and Eco-Innovation on Sustainability Performance. Procedia Social and Behavioral Sciences, v. 99, p. 154-163, 2013.

SICOTTE, H.; DROUIN, N.; DELERUE, H. Innovation Portfolio Management as a Subset of Dynamic Capabilities: measurement and impact on innovative performance. Project Management Journal, v. 45, n. 6, p. 58-72, 2014.

SILVIUS, A. J. G. et al. Sustainability in project management. Farnham: Gower Publishing, 2012. 
SILVIUS, A.; SCHIPPER, R. A conceptual model for exploring the relationship between sustainability and project success. Procedia Computer Science, v. 64, p. 334-342, 2015.

SU-YUN, S.; JUNG-MIN, H. The Sustainable Green Fashion Marketing Strategies according to Classification of Green Fashion Marketing of Domestic Fashion Companies. The Research Journal of the Costume Culture, v. 18, n. 5, 2010.

TARIQ, A. et al. Drivers and consequences of green product and process innovation: a systematic review, conceptual framework, and future outlook. Technology in Society, v. 51, p. 8-23, 2017.

TURNER, R.; LEDWITH, A.; KELLY, J. Project management in small to medium-sized enterprises: matching processes to the nature of the firm. International Journal of Project Management, v. 28, n. 8, p. 744-755, 2010.

WILLEMS, T. et al. Practices of isolation: the shaping of project autonomy in innovation projects. International Journal of Project Management, v. 38, n. 4, p. 215-228, 2020. 